\title{
The history of renal transplantation in Canada
}

\author{
Max Alexander Levine ${ }^{1}$; Joseph L Chin ${ }^{2}$; Andrew Rasmussen ${ }^{1}$; Alp Sener ${ }^{1}$; Patrick Luke ${ }^{1}$ \\ ${ }^{1}$ Western University, Department of Surgery, Division of Urology, Multiorgan Transplant Program, London, ON, \\ Canada; ${ }^{2}$ Western University, Department of Surgery, Division of Urology, London, ON, Canada
}

Acknowledgements: The authors would like to thank all the trainees, transplant surgeons, and physicians who contributed to this manuscript, including Drs. Yves Caumartin, Anil Kapoor, Joe Lawen, Vivian McAlister, Tom McGregor, Ron Moore, Mike Moser, Chris Nguan, Ken Pace, Steve Paraskevas,, Calvin Stiller, Darin Treleaven, and Jeff Warren.

Cite as: Can Urol Assoc J 2020 June 16; Epub ahead of print. http://dx.doi.org/10.5489/cuaj.6744

Published online June 16, 2020

$* * *$

\section{Abstract}

While the urologist's involvement in kidney transplantation varies from center to center and country to country, urologists remain integral to many programs across Canada. From the early days of kidney transplant to contemporary times, the leadership, vision, and skillset of Canadian urologists have helped progress the field. In this review of Canadian urologists' role in kidney transplantation, the achievements of this professional group are highlighted and celebrated. Original contributors to the field, as well as notable achievements are highlighted, with a focus on the impact of Canadian urologists. 


\section{The early days of kidney transplantation}

The role of the Urologist in kidney transplantation parallels the history of the procedure itself. Dr. Hartwell Harrison was the Urologist present at what is widely considered the first successful human kidney transplant between identical twins in 1954. In actual fact, it was a Canadian surgeon (Dr. Gordon Murray) who first performed a successful deceased donor transplant in 1952. ${ }^{1}$ This recipient survived over 35 years after her transplant. Unfortunately, what Dr. Murray possessed in surgical genius was countered by a lack of planning for long-term follow up, monitoring, and documentation of his surgical successes. This has led to questions about whether the transplant was successful or whether the patient's underlying disease improved, especially in the nascent years of immunosuppression. ${ }^{1}$ Nonetheless, the technique of transplant performed by Dr. Murray in 1952 represents a technique nearly identical to that employed today. ${ }^{2}$ Since this early period, Urologists have played an important role in the development, dispersion, and advancement of transplant surgery in Canada.

The launch of Canada into the new era of kidney transplantation occurred in 1958 at McGill University, where a transplant team comprised of Urologist Dr. Ken MacKinnon, vascular surgeon Dr. Joe Luke, and the team led by Dr. John Dossetor successfully transplanted the first living donor pair of identical twins in Canada. ${ }^{3}$ This recipient survived another three decades. The first repeat transplant was performed in Saskatoon by a pioneering team in 1964 led by nephrologist Dr. Marc Baltzan, along with Urologists Drs. Casamir Wolan and Manuel Ty. The Urology team at The Hospital for Sick Children (Sick Kids, Toronto), led by Drs. Bernard Churchill and nephrologist Dr. Gerald Arbus, pioneered pediatric renal transplantation in the late 1960s and by 1988 published factors influencing graft survival in their first 300 allografts. ${ }^{4}$ Other triumphs of kidney transplant have come from Urologists across the country. In 1972, Dr. Rex Boake from the University of Alberta performed a deceased donor transplant into a recipient who continues to enjoy a functioning allograft 48 years later, making this allograft one of the longest surviving transplants ever reported (Fig. 1). ${ }^{5}$

Urologists have helped launch successful kidney transplant programs in centres across the country. Many programs have recently celebrated their $50^{\text {th }}$ anniversary of kidney transplant, including several with Urologists as part of the foundation of these programs. These include the University of British Columbia (1968), University of Alberta (Dr. William Lakey, 1967) (Fig. 2), University of Saskatchewan (Drs. Casamir Wolan and Manuel Ty, 1964), St. Michael's Hospital in Toronto (Dr. Nick Colapinto, 1969), Queen's University (Dr. Andrew Bruce, 1968), McMaster University (Drs. Peter Knight and Art Shimazu, 1974), Western University (Drs. John Sharpe, Lloyd McAninch and Nick Gergley, 1972, University of Ottawa (Drs. Irvine and Koch, 1967), Dalhousie University (Drs. Allan MacDonald and Stan Lannon, 1969), Health Sciences Centre Winnipeg (Dr. Allan Downs, 1969), and L'Hôtel-Dieu de Québec, Quebec City (Drs. Roméo Charrois, and Gilles Laroche, 1972). Table 1 summarizes the emergence of the kidney 
transplant programs around most of the major Canadian centres. The early foothold in kidney transplantation by several Urology programs set the stage for transplant innovation by the Urologic community.

\section{Advances in kidney donation}

Despite success in living and neurologic death kidney donation, the imbalance between the number of kidney donors and recipients force thousands across Canada to remain on the waitlist for a kidney. Measures to increase the number of possible organ donors have included the reemergence of donation after circulatory death (DCD) kidney donation, as well as innovations in living donor techniques.

After physicians at St. Michael's Hospital (Toronto) spearheaded donor withdrawal protocols for DCD donation, Dr. John Mahoney and the transplant group from the University of Ottawa led the way with the first deceased donor transplant from a DCD donor in 2006. St. Michael's Hospital and University Hospital (Western University) transplant programs followed shortly with their first DCD donor transplants in the same year. Western University then performed the first pediatric DCD donor kidney transplant in 2008, and the first Canadian DCD combined kidney-pancreas transplantation in 2008. .,7 $^{6}$

Following the first laparoscopic donor nephrectomy reported in 1995 by Dr. Lloyd Ratner and Dr. Louis Kavoussi, organ donors were finally offered a minimally invasive alternative to the painful flank or subcostal incision for live kidney donation. ${ }^{8}$ Shortly after the first Canadian case was performed in Montreal, the St. Michael's team performed the first case in Ontario. Dr. Ken Pace and the St. Michael's team published a prospective case series outlining the advantages of laparoscopic donor nephrectomy thereby establishing minimally invasive techniques as the standard of care for living donation in the early 2000's. ${ }^{9-11}$ By 2009, Dr. Anil Kapoor published an illustrative guide to right sided laparoscopic donor nephrectomy, helping advance the field toward access to minimally invasive donation regardless of kidney laterality. ${ }^{7}$ In 2013, Drs. Alp Sener and Patrick Luke at Western University performed the first robotic single site (R-LESS) donor nephrectomy in Canada. The same team would go on to publish a series of R-LESS donation compared to laparoscopic donation, demonstrating improved cosmesis and patient satisfaction. ${ }^{12}$ Laparoscopic living kidney donation is now offered at all Canadian transplant centres with Urologists consistently advancing the field.

The criteria for accepting living donors has been further developed through the work of Canadian Urologists. During his time in Winnipeg, Dr. Tom McGregor published outcomes from a series of living donor kidneys where ex-vivo renal surgery was employed to manage issues that historically would have caused potential donors to be ineligible to donate. ${ }^{13}$ In this series, $11 \%$ of consecutive kidney donors at a single institution were managed with "back table" ex-vivo surgery, including ureteroscopy, partial nephrectomy for angiomyolipoma, open nephrolithotomy and calyceal diverticulum ablation. (Fig. 3) While at Maryland, Dr. Alp Sener published a series of patients who underwent ex vivo partial nephrectomy for renal masses (3/5 
with renal cell carcinoma) prior to living donor renal transplantation. ${ }^{14}$ Dr. Neal Rowe and the Urology group in Ottawa followed this up by performing a systematic review of transplanted kidneys from donors with small renal masses and confirmed the safety of this practice. ${ }^{15}$ Given that these procedures are uniquely within the armamentarium of most, if not all Urologists, our participation in kidney transplantation has had a significant impact on increasing the donor pool.

\section{Live donor paired exchange}

In 2003, Dr. Bill Gourlay and the transplant group from St. Paul's Hospital in Vancouver published a seminal paper documenting various psychosocial profiles of potential anonymous living kidney donors and created a framework for developing ethical and safe policies around accepting anonymous donors. ${ }^{16}$ This Canadian led publication set the groundwork for living donor paired exchanges (LDPE) to take place across North America. Further work by Dr. Tom McGregor from Queen's University assessed the hardships in transporting organs across a country as large as Canada. ${ }^{17}$

The very first paired exchange of living donor kidneys in Canada took place in 2004 between St. Michael's Hospital in Toronto and University Hospital Network (Toronto). ${ }^{18}$ By 2009, Canada performed the first multi-donor long distance kidney paired exchange in 2009, involving a "swap" between Toronto, Edmonton, and Vancouver. ${ }^{19}$ This achievement speaks to the cohesiveness and tenacity of the Canadian transplant community, overcoming the great distance between our centres to come together to help save lives. Dr. Jeff Veale, a Canadian Urologist at UCLA, has orchestrated many of the largest paired exchanges in the world, including a 30-pair chain in 2012. ${ }^{20}$ One of the greatest successes in organized transplantation medicine world-wide is the Canadian Blood Service driven LDPE and Highly Sensitized Patient Program, which provides matching of organs to highly sensitized patients across Canada. Together, these programs have led to over 1000 transplants that otherwise would never have occurred.

\section{Immunosuppression}

Prior to modern day immunotherapy, donor-specific blood transfusions were used to accompany the kidney transplant procedure. Dr. Calvin Stiller, a nephrologist from Western University along with Urologists Drs. Eric Shepherd, Jack Sharpe, and Phil Hayman showed that transfusion of donor blood on the same day of transplant improved graft survival. ${ }^{21}$ This beneficial effect persisted in practice until the discovery of cyclosporine in the early 1980's by Dr. Jean Francois Borel in Switzerland. Cyclosporine was the first calcineurin inhibitor utilized in clinical practice and became the backbone of immunosuppressive protocols for decades. Dr. Stiller served as the Principal Investigator in the landmark randomized controlled multicentre trial comparing cyclosporine to azathioprine in Canada. This launched cyclosporine into the forefront of kidney, and all solid organ transplant immunosuppression. ${ }^{22}$ Canadian Urologists Dr. Phil Belitsky, Dr. Joe Lawen, and colleagues at Dalhousie University further refined the utilization of cyclosporine. 
Their research demonstrated improved performance of the $2 \mathrm{hr}$ concentration (C2 level) as a superior marker of cyclosporine exposure compared to trough levels, improving the efficacy of this vital drug. ${ }^{23}$ Cyclosporine was a "game changer" in the world of transplant, and the calcineurin inhibitor remains the cornerstone of transplant immunosuppression regimens. Dr. Andrew Lazarovits from Ottawa and London discovered a monoclonal antibody called antiCD45RB. ${ }^{24}$ Subsequently, Dr. Luke and his research group showed that this antibody shifted the $\mathrm{T}$ cell subsets from effector $\mathrm{CD} 45 \mathrm{RB}^{\text {hi }}$ to $\mathrm{CD} 45 \mathrm{RB}^{\text {lo }}$, a tolerogenic $\mathrm{T}$ cell phenotype. ${ }^{25,26}$ In fact, a team of scientists, physicians and surgeons from Western University (Drs. Robert Zhong, Anthony Jevnikar and Patrick Luke) showed that this antibody could induce tolerance in mice and in primates (indefinite graft survival with a limited induction course). ${ }^{27,28}$ Two primates continue to survive and remain off immunosuppression over a decade later. This was a remarkable achievement, but the efficacy was unpredictable and it was never clear which animals would reject early and which developed tolerance.

\section{Techniques}

Around the time that microvascular reconstruction for kidneys with complex branch renal artery arrangements was first described by Canadian-born Urologist Dr. Andrew Novick at the Cleveland Clinic in the early 1980's ${ }^{29,30}$, Dr. Joseph Chin incorporated pre-operative ex vivo microvascular reconstruction into the surgical algorithm for renal allografts. ${ }^{31,32}$ Kidneys with multiple arteries and/or veins, and those with certain vascular anomalies (e.g. aneurysms) or injuries during procurement were reconstructed in an ice-water basin with $2.5-10 \mathrm{X}$ magnification (with optical loupes or microscope) with the objective of minimizing the number of in situ vascular anastomoses. Side-to-side or end-to-side anastomosis or a combination thereof was performed, depending on the initial vascular arrangement (Fig. 4). ${ }^{33,34}$ Ex-vivo microvascular reconstruction was performed by Dr. Chin on 104 allografts (83 deceased donor, 21 living donor). ${ }^{35}$ While 74 kidneys underwent a single micro-reconstruction, 30 kidneys with 3 or more arteries or previously deemed unsuitable for transplant were salvaged with extensive preoperative microvascular reconstruction.

Due to limited graft survival or high risk of complication, kidneys from older or young pediatric donors are often discarded. Kidneys conventionally considered too old or too young for transplant are now able to be used since the concept of transplanting two kidneys into a single patient took hold. Urologist Dr. Yves Caumartin and the Laval group published one of the largest series of dual transplant procedures at the time, utilizing kidneys that were deemed too old for solitary transplantation. ${ }^{36}$ They showed that although ureteral complications may be higher, dual transplants from expanded criteria (older) donors had function and graft survival similar to transplants from younger, standard criteria kidney donors. Taking this further, the Western University team published a series of 30 dual en bloc transplants from older donors, which utilized ex vivo vascular reconstruction techniques to facilitate solitary arterial and venous anastomoses during the in vivo transplant procedure. ${ }^{37}$ While in Cleveland, Drs. Michael Hobart 
and Anil Kapoor characterized excellent early technical results in transplanting pediatric en bloc kidneys. ${ }^{38}$ In the following years, in a collaborative effort between the Dalhousie and Western groups, the dual en bloc technique was shown to have excellent results in pediatric donors under the age of 2 years. ${ }^{39}$ By 2019, the Western group extended this microvascular technique to transplant kidneys from donors as young as 2 weeks of age. ${ }^{40}$

Transplantation of kidneys into the dysfunctional lower urinary tract has been an area that has specifically called for Urologic expertise. Dr. Phil Belitsky from Dalhousie University first described ureteral dynamics in human transplants using a cineradiographic study in 1972. Dr. Joe Lawen, from the same centre, performed one of the first randomized studies that compared the use of the ureteral stent vs. no stent during ureteral implantation in renal transplantation and concluded that routine stenting may not be necessary. ${ }^{41}$ However, despite the results of this study, the majority of Canadian transplant surgeons continue to utilize stents routinely. ${ }^{42}$ With regards to transplantation into the hostile lower urinary tract, Dr. Marie Dion, while at Western University, described a predictive algorithm that determined post-operative lower urinary dysfunction post-transplant. ${ }^{43}$ Early successful transplants into urinary conduits provided eligibility for children with dysfunctional lower urinary tracts to receive kidney transplants. ${ }^{44}$ Dr. Luke, while training at the University of Pittsburgh under Canadian Urologist Dr. Mark Jordan, demonstrated equivalent allograft outcomes in pediatric patients with dysfunctional lower urinary tracts compared to those with normal bladders, provided that adequate lower urinary tract assessment had been performed. ${ }^{45}$ Accordingly, Drs. Belitsky and Chin individually showed good outcomes in adults with diversions and defunctionalized bladders. ${ }^{46,47}$ Furthermore, if the bladder or intestinal reservoir were inappropriate urinary reservoirs, Dr. Kapoor and his group showed that they could be excluded by creation of a terminal loop cutaneous ureterostomy from the transplant ureter. ${ }^{48}$ In addition to complex implantation of the ureter, Canadian Urologists have described algorithms to optimally repair ureteral strictures as well as provide descriptions and assessments of repair techniques. ${ }^{49-51}$

\section{Renal protection}

The discovery of cold perfusate solutions such as University of Wisconsin Belzer solution, and utilization of hypothermic machine perfusion devices have been shown to protect kidneys against deterioration during prolonged cold storage. ${ }^{52,53}$ In a donor matched prospective study, Dr. Chris Nguan, while at Western University, showed that the calcium channel blocker verapamil further protects the allograft when injected into cold perfusate solution. ${ }^{54}$ Dr. Nguan's group at Vancouver General have also assessed modification of Belzer solution with hyperbranched polyglycerol. ${ }^{55}$ Additionally, Drs. Sener and Luke have shown that small endogenous molecules such as carbon monoxide and hydrogen sulfide reduce ischemia reperfusion injury, improve vascular compliance, and reduce cell death when administered to kidney donors, recipients and even directly to the kidney ex vivo. ${ }^{56-59}$ Sener further explored the ability of $\mathrm{H} 2 \mathrm{~S}$ in creating a hibernation-like state for transplantable organs. ${ }^{60}$ The Western team have created a device which 
can deliver oxygen to the organs through a blood-free hemoglobin carrier under conditions that avoids hypothermic injury to the organs, with superior outcomes to hypothermic machine perfusion. ${ }^{61}$ (Fig. 5) In a pre-clinical large animal model, this pump has been shown to be superior to hypothermic machine perfusion in the prevention of ischemia reperfusion injury. ${ }^{62}$ Furthermore, addition of anti-inflammatory agents such as $\mathrm{H}_{2} \mathrm{~S}$ or $\mathrm{CO}$ can be performed ex vivo to further protect the organ from reperfusion injury. ${ }^{63-66}$

\section{Auto-transplantation}

Renal auto-transplantation is a surgical procedure firmly in the realm of the Urologist since the 1960s. It represents a treatment option for those with complex/large ureteric strictures as well as loin pain hematuria syndrome. Dr. Chin published the largest North American series in 1992 with updates in 1998, demonstrating the durable results in freeing patients of loin pain hematuria syndrome from narcotic dependency. ${ }^{67,68}$ Further advancement of the auto-transplant procedure was performed by Dr. Jason Lee from the University of Toronto, who reported the first purely intracorporeal robotic renal auto-transplant in $2015 .^{69}$ (Fig. 6)

\section{Renal vascular surgery}

The skillset of the Transplant Urologist lends aptitude to other complex renal surgery such as renal vascular cases. Drs. Kapoor and Luke presented the largest known series of minimally invasive repair of renal artery aneurysms (RAA). In 2006, Kapoor and Luke demonstrated a series of 3 patients with RAA, managed in 2 cases $^{70}$ with a laparoscopic and 1 with a robotic approach. ${ }^{71}$ The integration of vascular surgical principles and practice of the Transplant Urologist lends capability to tackling these challenging cases.

\section{Transplant training}

Surgical training in renal transplant has continued to evolve as the field matured in contemporary times. The early days saw Urologists drawn to the field of transplant entering the practice directly, but as with many subspecialties, formal fellowships have shaped the training for most Transplant Urologists. The American Society of Transplant Surgeons (ASTS) educational committee has served as the benchmark for establishing the standards of transplant surgical training since $1980 .^{72}$ ASTS certification in kidney transplantation has been granted to several Canadian institutions involving Urologists, including the University of Alberta, Western University, and Dalhousie University. As a critical mass of Canadian contributors to the field of solid organ transplant grew over the years, the development of Canadian credentials emerged. The Royal College of Physicians and Surgeons has created an Area of Focused Competence designation in several subspecialties, including Solid Organ Transplant. ${ }^{73}$ Currently, 2 programs in Canada are accredited under this emerging framework (University of Ottawa, Western University), with a third in the process of becoming accredited. This evolving form of 
accreditation will serve to set national benchmarks for training quality while improving the recognition and access to transplant training for Urology trainees across Canada.

\section{Summary}

Urologists in Canada have provided leadership roles in renal transplantation since its inception and continue to do so in the current era. Urologists' early and ongoing participation in renal transplant have afforded the current generation the opportunity to establish Canadian Urology as significant players in the transplant field and has set the stage for the next generation of Urologists to continue this important work for years to come.

\section{References:}

1. McKellar S. The Career of Gordon Murray: Patterns of Change in Mid-Twentieth Century Medicine in Canada. https://www.collectionscanada.gc.ca/obj/s4/f2/dsk1/tape9/PQDD_0003/NQ41240.pdf. Published 1999. Accessed Feb 25, 2020.

2. McAlister V. Surgical Limits: The Life of Gordon Murray. Can J Surg 2004;47(5):38889.

3. McGill University Health Centre celebrates 50th anniversary of Canada's 1st kidney transplant. https://www.mcgill.ca/channels/news/mcgill-university-health-centrecelebrates-50th-anniversary-canada's-1st-kidney-transplant-102108. Published 2008. Accessed.

4. Churchill BM, Sheldon CA, McLorie GA, et al. Factors influencing patient and graft survival in 300 cadaveric pediatric renal transplants. J Urol 1988;140(5 Pt 2):1129-33.

5. Bauer K. Pioneering Transplant Surgeon honours his profession with gift of education. https:/www.ualberta.ca/medicine/news/2018/november/pioneering-transplant-surgeonhonours-his-profession-with-gift-of-education. Published 2018. Accessed Feb 25, 2020.

6. Anderson PT, Aquil S, McLean K, et al.. First Canadian experience with donation after cardiac death simultaneous pancreas and kidney transplants. Can J Surg 2017;60(5):32328.

7. Important Dates in Transplantation. https://www.lhsc.on.ca/multi-organ-transplantprogram/important-dates-in-transplantation. Published 2019. Accessed Feb 25, 2020.

8. Ratner LE, Ciseck LJ, Moore RG, et al. Laparoscopic live donor nephrectomy. Transplantation. 1995;60(9):1047-1049.

9. Pace KT, Dyer SJ, Phan V, et al. Laparoscopic v open donor nephrectomy: a cost-utility analysis of the initial experience at a tertiary-care center. $J$ Endourol 2002;16(7):495-508.

10. Pace KT, Dyer SJ, Stewart RJ, et al. Health-related quality of life after laparoscopic and open nephrectomy. Surg Endosc 2003;17(1):143-152. 
11. Pace KT, Dyer SJ, Phan V, et al. Laparoscopic versus open donor nephrectomy. Surg Endosc 2003;17(1):134-42.

12. Luke PP, Aquil S, Alharbi B, Sharma H, Sener A. First Canadian experience with robotic laparoendoscopic single-site vs. standard laparoscopic living-donor nephrectomy: A prospective comparative study. Can Urol Assoc J 2018;12(11):E440-46.

13. McGregor TB, Rampersad C, Patel P. Expanding living kidney donor criteria with exvivo surgery for renal anomalies. Can Urol Assoc J 2016;10(9-10):301-05.

14. Sener A, Uberoi V, Bartlett ST, et al. Living-donor renal transplantation of grafts with incidental renal masses after ex-vivo partial nephrectomy. BJU Int 2009;104(11):165560.

15. Cristea $\mathrm{O}$, Warren J, Blew B, et al. Transplanting kidneys from donors with small renal masses - a strategy to expand the donor pool. Can Urol Assoc J 2020;14(1):E32-E38.

16. Henderson AJ, Landolt MA, McDonald MF, et al. The living anonymous kidney donor: lunatic or saint? Am J Transplant 2003;3(2):203-13.

17. McGregor T, Sener A, Paraskevas S, et al. Kidney paired donation and the unique challenges of kidney shipment in Canada. Can J Surg 2018;61(2):8017.

18. Garrels MCaM. Kidney Paired Donation The Why And The How. https://www.stmichaelshospital.com/pdf/programs/renal-transplant/kidney-paireddonation.pdf. Published 2010. Accessed.

19. Multi-donor, long-distance kidney swap a first in Canada. CBC. https://www.cbc.ca/news/technology/multi-donor-long-distance-kidney-swap-a-first-incanada-1.788562. Published 2009. Accessed Feb 27, 2020.

20. FOX News Highlights 60-person Kidney Chain | UCLA Kidney Exchange Program. Fox News2012.

21. Stiller CR, Lockwood BL, Sinclair NR, et al. Beneficial effect of operation-day bloodtransfusions on human renal-allograft survival. Lancet 1978;1(8057):169-70.

22. Stiller CR. Update for the Canadian multicentre trial of cyclosporine in renal allografts. $N$ Engl J Med 1984;310(22):1464-65.

23. Mahalati K, Belitsky P, West K, et al. Approaching the therapeutic window for cyclosporine in kidney transplantation: a prospective study. J Am Soc Nephrol 2001;12(4):828-33.

24. Lazarovits AI, Poppema S, Zhang Z, et al. Therapy for mouse renal allograft rejection by monoclonal antibody to CD45RB. Transplant Proc 1996;28(6):3208-09.

25. Luke PP, Deng JP, O'Brien CA, et al. Alteration in CD45RBhi/CD45RBlo T-cell ratio following CD45RB monoclonal-antibody therapy occurs by selective deletion of CD45RBhi effector cells. Transplantation 2003;76(2):400-09. 
26. Luke PP, Deng JP, Lian D, et al. Prolongation of allograft survival by administration of anti-CD45RB monoclonal antibody is due to alteration of CD45RBhi: CD45RBlo T-cell proportions. Am J Transplant 2006;6(9):2023-34.

27. Luke PP, O'Brien CA, Jevnikar AM, et al. Anti-CD45RB monoclonal antibody-mediated transplantation tolerance. Curr Mol Med 2001;1(5):533-43.

28. Chen G, Luke PP, Yang H, et al. Anti-CD45RB monoclonal antibody prolongs renal allograft survival in cynomolgus monkeys. Am J Transplant 2007;7(1):27-37.

29. Novick AC, Stewart BH, Straffon RA. Extracorporeal renal surgery and autotransplantation: indications, techniques and results. J Urol 1980;123(6):806-11.

30. Templin R, Bast R, Seemann B, et al. Microsurgical blood vessel reconstruction in kidney transplantation]. Z Urol Nephrol 1984;77(1):25-30.

31. Chin JL, Stiller CR. Microvascular surgery as an adjunctive tool in renal transplantation. Can J Surg 1986;29(4):263-66.

32. Chin J, Zhong R, Duff J, Stiller C. Microsurgical renal transplant models in rats: a comparison of four anastomotic techniques. Transplant Proc 1989;21(2):3351-52.

33. Lakey WH. Kidney preservation: experimental studies. Trans Am Assoc Genitourin Surg 1977;69:125-30.

34. Chin JL. Microvascular reconstructive "bench: for donor kidneys prior to transplantation: Techniques and results. J. Urol 1989; 142

35. Chin JL, Yip SK, McFarlane N. Clinical impact of adjunctive donor microvascular reconstruction on renal transplantation. Can J Urol 2003;10(2):1803-08.

36. De Serres SA, Caumartin Y, Noel R, et al. Dual-kidney transplants as an alternative for very marginal donors: long-term follow-up in 63 patients. Transplantation 2010;90(10):1125-30.

37. Tran KC, Li D, Taqi A, et al. Dual en bloc technique for adult renal transplantation. Clin Transplant 2017;31(8).

38. Hobart MG, Modlin CS, Kapoor A, et al. Transplantation of pediatric en bloc cadaver kidneys into adult recipients. Transplantation 1998;66(12):1689-94.

39. Beasley KA, Balbontin F, Cook A, et al. Long-term follow-up of pediatric en bloc renal transplantation. Transplant Proc 2003;35(7):2398-99.

40. Mitrou N, Aquil S, Dion M, et al. Transplantation of pediatric renal allografts from donors less than $10 \mathrm{~kg}$. Am J Transplant 2018;18(11):2689-94.

41. Dominguez J, Clase CM, Mahalati K, et al. Is routine ureteric stenting needed in kidney transplantation? A randomized trial. Transplantation 2000;70(4):597-601.I

42. Reynolds LF, Kroczak T, Honey RJ, et al. A survey of Canadian renal transplant surgeons: Use of ureteric stents and technique of the ureteroneocystotomy. Can Urol Assoc J 2018 12(12):415-18. 
43. Dion M, Cristea O, Langford S, et al. Debilitating lower urinary tract symptoms in the post-renal transplant population can be predicted pretransplantation. Transplantation 2013;95(4):589-94.

44. Kelly WD, Merkel FK, Markland C. Ileal urinary diversion in conjunction with renal homotransplantation. Lancet 1966;1(7431):222-26.

45. Luke PP, Herz DB, Bellinger MF, et al. Long-term results of pediatric renal transplantation into a dysfunctional lower urinary tract. Transplantation 2003;76(11):1578-82.

46. Hatch DA, Belitsky P, Barry JM, et al. Fate of renal allografts transplanted in patients with urinary diversion. Transplantation 1993;56(4):838-42.

47. Chin JL, Elsdon TC, Sharpe JR. Revision of urinary diversion and renal transplantation. Transplant Proc 1989;21(2):3321-3322.

48. Tsai SY, Chang CY, Piercey K, Kapoor A. Terminal loop cutaneous ureterostomy in renal transplantation: an under utilized urinary diversion technique. J Urol 2005;174(5):1906-09.

49. Kwong J, Schiefer D, Aboalsamh G, et al. Optimal management of distal ureteric strictures following renal transplantation: a systematic review. Transpl Int 2016;29(5):579-88.

50. McGregor T, Kroczak T, Huang C, et al.Ureteric re-implant for the strictured renal allograft: How I do it. Can J Urol 2016;23(3):8296-300.

51. Kroczak T, Koulack J, McGregor T. Management of Complicated Ureteric Strictures After Renal Transplantation: Case Series of Pyelovesicostomy With Boari Flap.

Transplant Proc 2015;47(6):1850-53.

52. Dion MS, McGregor TB, McAlister VC, et al.. Hypothermic machine perfusion improves Doppler ultrasonography resistive indices and long-term allograft function after renal transplantation: a single-centre analysis. BJU Int 2015;116(6):932-37.

53. Bathini V, McGregor T, McAlister VC, et al. Renal perfusion pump vs cold storage for donation after cardiac death kidneys: a systematic review. J Urol 2013;189(6):2214-20.

54. Nguan CY, Sener A, Karnik V, et al. Perfusion of renal allografts with verapamil improves graft function. Transplantation 2008;86(10):1463-67.

55. Gao S, Guan Q, Chafeeva I, et al. Hyperbranched polyglycerol as a colloid in cold organ preservation solutions. PLoS One 2015;10(2):e0116595.

56. Caumartin Y, Stephen J, Deng JP, et al. Carbon monoxide-releasing molecules protect against ischemia-reperfusion injury during kidney transplantation. Kidney Int 2011;79(10):1080-89.

57. Lobb I, Davison M, Carter D, et al. Hydrogen Sulfide Treatment Mitigates Renal Allograft Ischemia-Reperfusion Injury during Cold Storage and Improves Early 
Transplant Kidney Function and Survival Following Allogeneic Renal Transplantation. J Urol 2015;194(6):1806-15.

58. Sener A, Tran KC, Deng JP, et al. Carbon monoxide releasing molecules inhibit cell death resulting from renal transplantation related stress. J Urol 2013;190(2):772-78.

59. Zhu JX, Kalbfleisch M, Yang YX, et al. Detrimental effects of prolonged warm renal ischaemia-reperfusion injury are abrogated by supplemental hydrogen sulphide: an analysis using real-time intravital microscopy and polymerase chain reaction. BJU Int 2012;110(11 Pt C):E1218-27.

60. Dugbartey GJ, Bouma HR, Saha MN, et al. A Hibernation-Like State for Transplantable Organs: Is Hydrogen Sulfide Therapy the Future of Organ Preservation? Antioxid Redox Signal 2018;28(16):1503-15.

61. Bhattacharjee RN, Patel SVB, Sun Q, et al. Renal Protection Against Ischemia Reperfusion Injury: Hemoglobin-based Oxygen Carrier-201 Versus Blood as an Oxygen Carrier in Ex Vivo Subnormothermic Machine Perfusion. Transplantation 2020;104(3):482-89.

62. Bhattacharjee RN, Ruthirakanthan A, Sun Q, et al. Subnormothermic Oxygenated Perfusion Optimally Preserves Donor Kidneys Ex Vivo. Kidney Int Rep 2019;4(9):132333.

63. Bhattacharjee RN, Richard-Mohamed M, Sun Q, et al. CORM-401 Reduces Ischemia Reperfusion Injury in an Ex Vivo Renal Porcine Model of the Donation After Circulatory Death. Transplantation 2018;102(7):1066-74.

64. Patel SVB, Sener A, Bhattacharjee RN, et al.. Machine preservation of donor kidneys in transplantation. Transl Androl Urol 2019;8(2):118-25.

65. Juriasingani S, Akbari M, Chan JY, et al. H2S supplementation: A novel method for successful organ preservation at subnormothermic temperatures. Nitric Oxide 2018;81:57-66.

66. Juriasingani S, Akbari M, Luke P, et al. Novel therapeutic strategies for renal graft preservation and their potential impact on the future of clinical transplantation. Curr Opin Organ Transplant 2019;24(4):385-90.

67. Chin JL. Loin pain-hematuria syndrome: role for renal autotransplantation. $J$ Urol 1992;147(4):987-89.

68. Chin JL, Kloth D, Pautler SE, et al. Renal autotransplantation for the loin pain-hematuria syndrome: long-term followup of 26 cases. J Urol 1998;160(4):1232-1235; discussion 1235-36.

69. Lee JY, Alzahrani T, Ordon M. Intra-corporeal robotic renal auto-transplantation. Can Urol Assoc J 2015;9(9-10):E748-49.

70. Anil Kapoor PL. LAPAROSCOPIC AND ROBOTIC REPAIR OF RENAL ARTERY ANEURYSMS. American Urologic Association; May 24, 2006, 2006. 
71. Luke P, Knudsen BE, Nguan CY, et al. Robot-assisted laparoscopic renal artery aneurysm reconstruction. J Vasc Surg 2006;44(3):651-53.

72. ASTS History: Accreditation of Training Programs, Fellowship Grants and Faculty Development, and Postgraduate Course. ASTS. https://asts.org/docs/defaultsource/about-asts/training-and-education.pdf?sfvrsn=2. Published 2020. Accessed Feb $28,2020$.

73. Areas of Focused Competence diploma discipline. http:/www.royalcollege.ca/rcsite/specialty-discipline-recognition/categories/disciplinerecognition-areas-focused-competence-afc-programs-e. Published 2020. Accessed Feb 28,2020 . 


\section{Figures and Tables}

Fig. 1. (A) Dr. Rex Boake is photographed with former patient Freda Ainlay. Ainlay has had a functioning kidney graft for 48 years. (B) Dr. Boake's graduation portrait. Reprinted with permission by the University of Alberta.
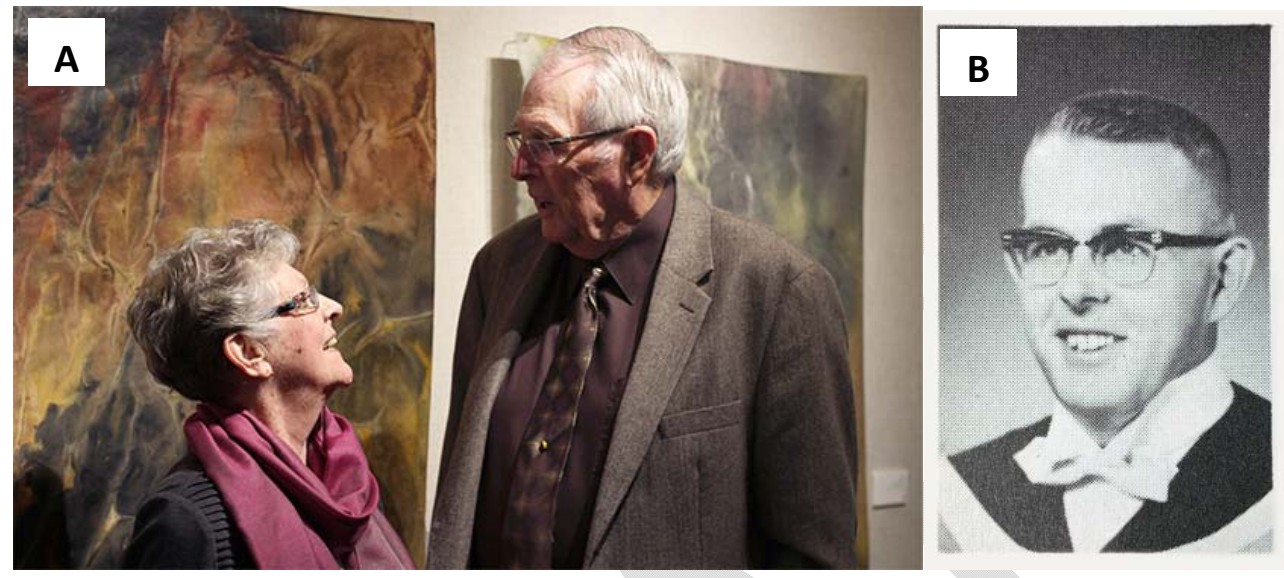

Fig. 2. Dr. William Lakey performs the first Kidney transplant in Alberta at the University of Alberta, Edmonton, AB in 1967. Reprinted with permission from Alberta Health Services. Original image supplied by AHS.

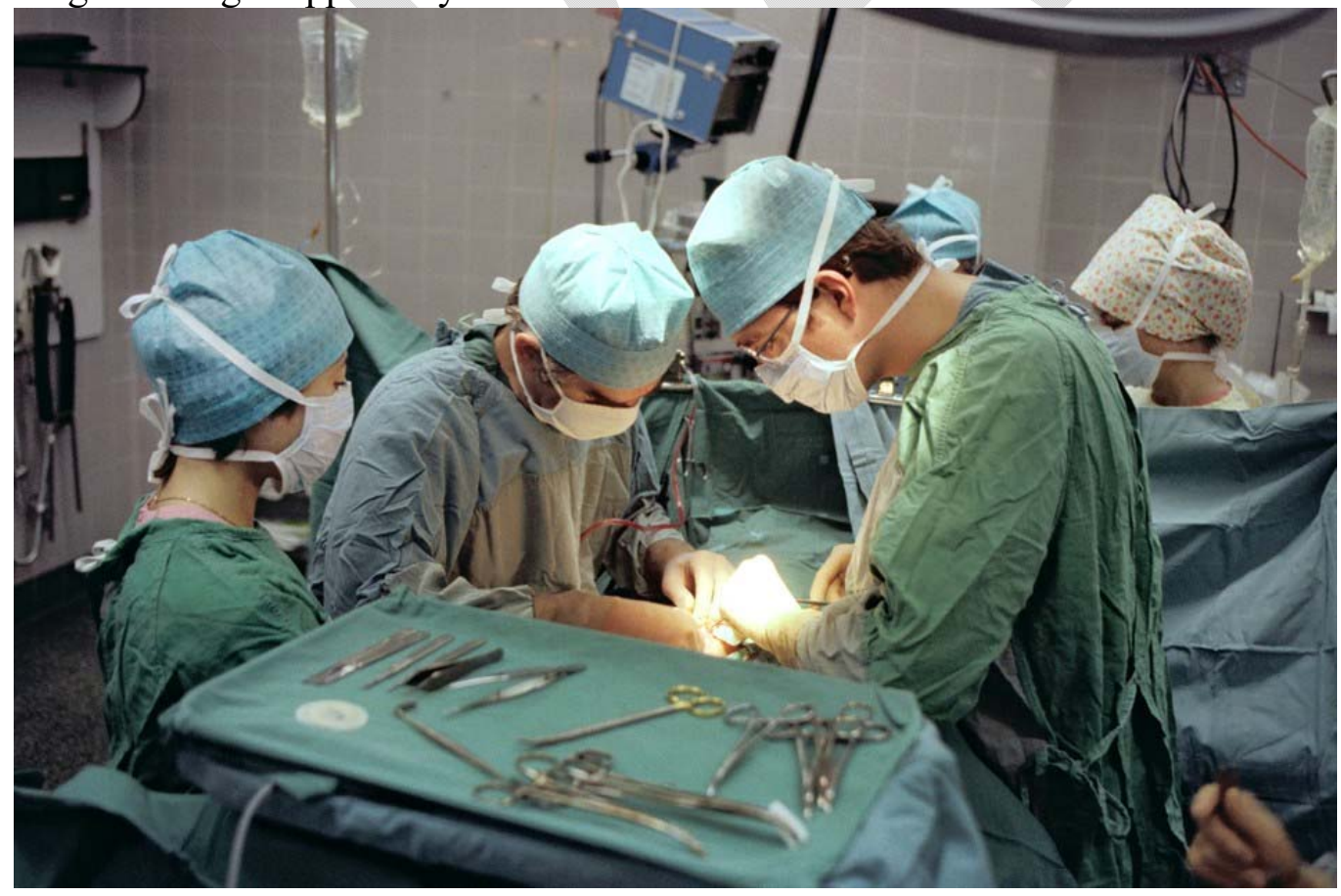


Fig. 3. Ex-vivo urologic surgery on kidney grafts. Reprinted with permission. McGregor TB, Rampersad C, Patel P. Expanding living kidney donor criteria with ex-vivo surgery for renal anomalies. Can Urol Assoc J 2016;10:301-5.

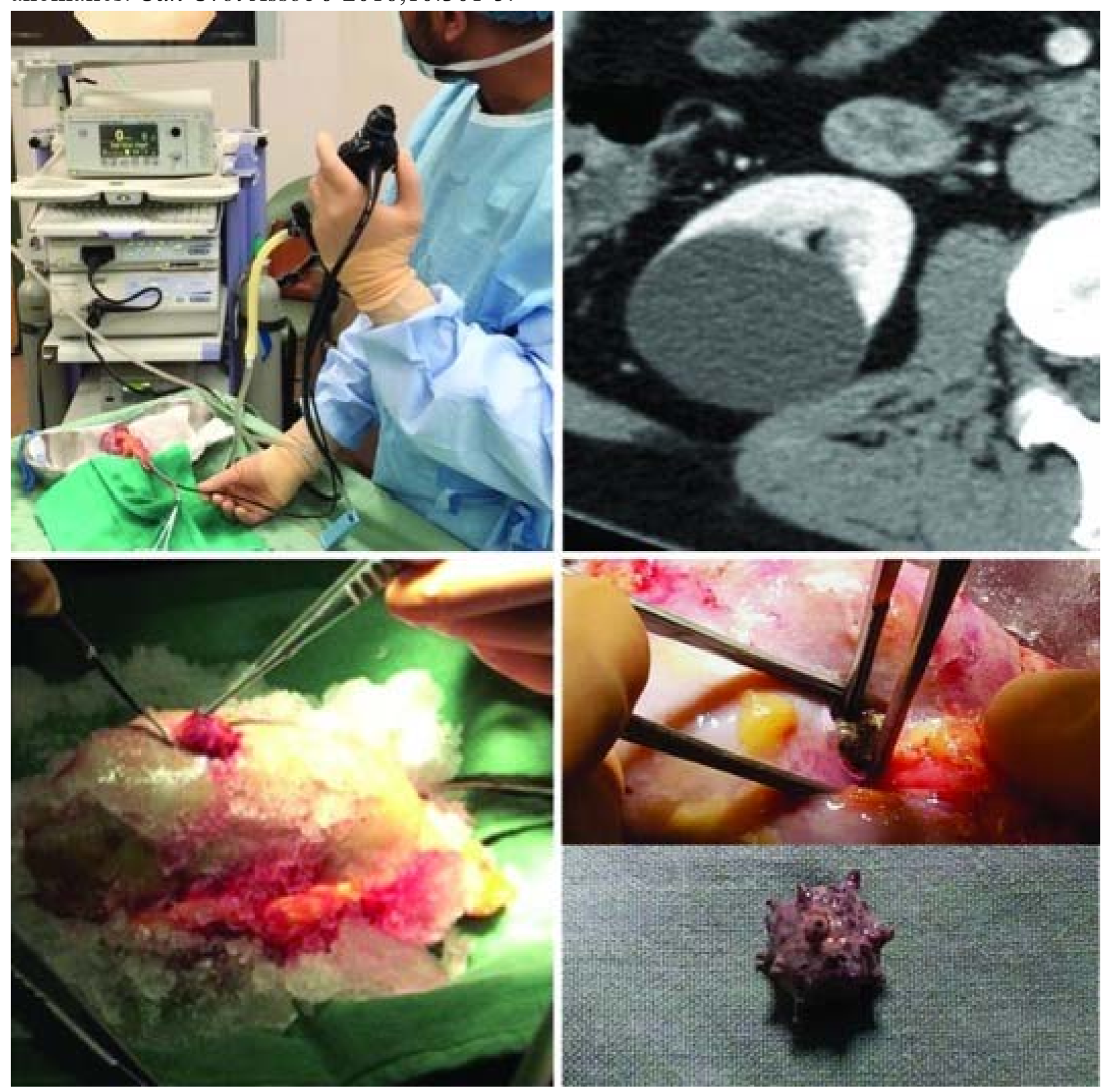


Fig. 4. Arterial reconstruction techniques pioneered by Dr. Chin and colleagues. Reprinted with permission. Chin JL, Stiller, CR. Microvascular surgery as an adjunctive tool in renal transplantation. Can J Surg 1986;29:263. Chin JL, Stiller, CR. Microvascular reconstructive "bench" surgery for donor kidneys before transplantation: Techniques and results. J Urol 1989; 142.
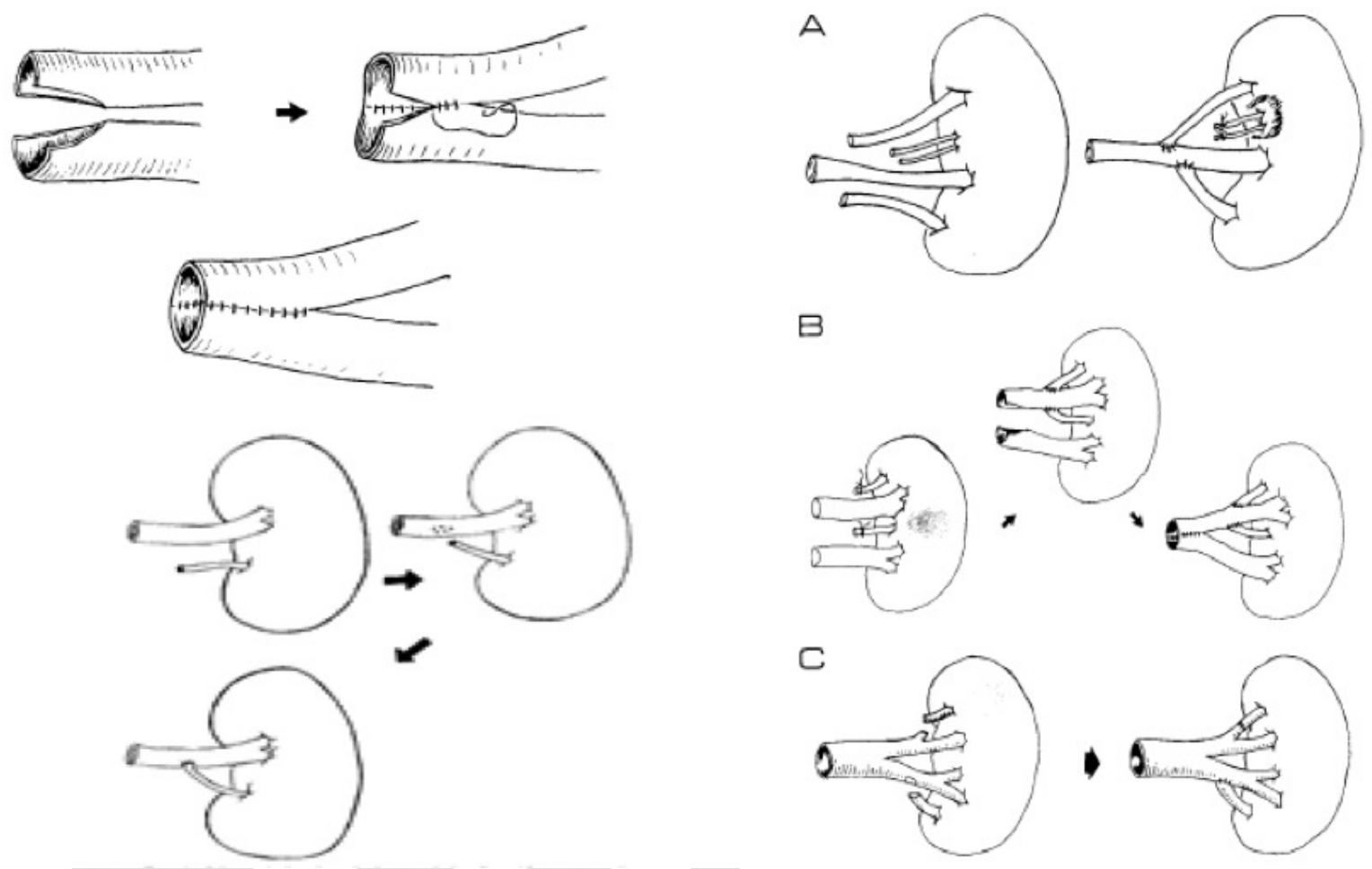
Fig. 5. Renal perfusion pump from the Luke Laboratory at Western University, London, ON.

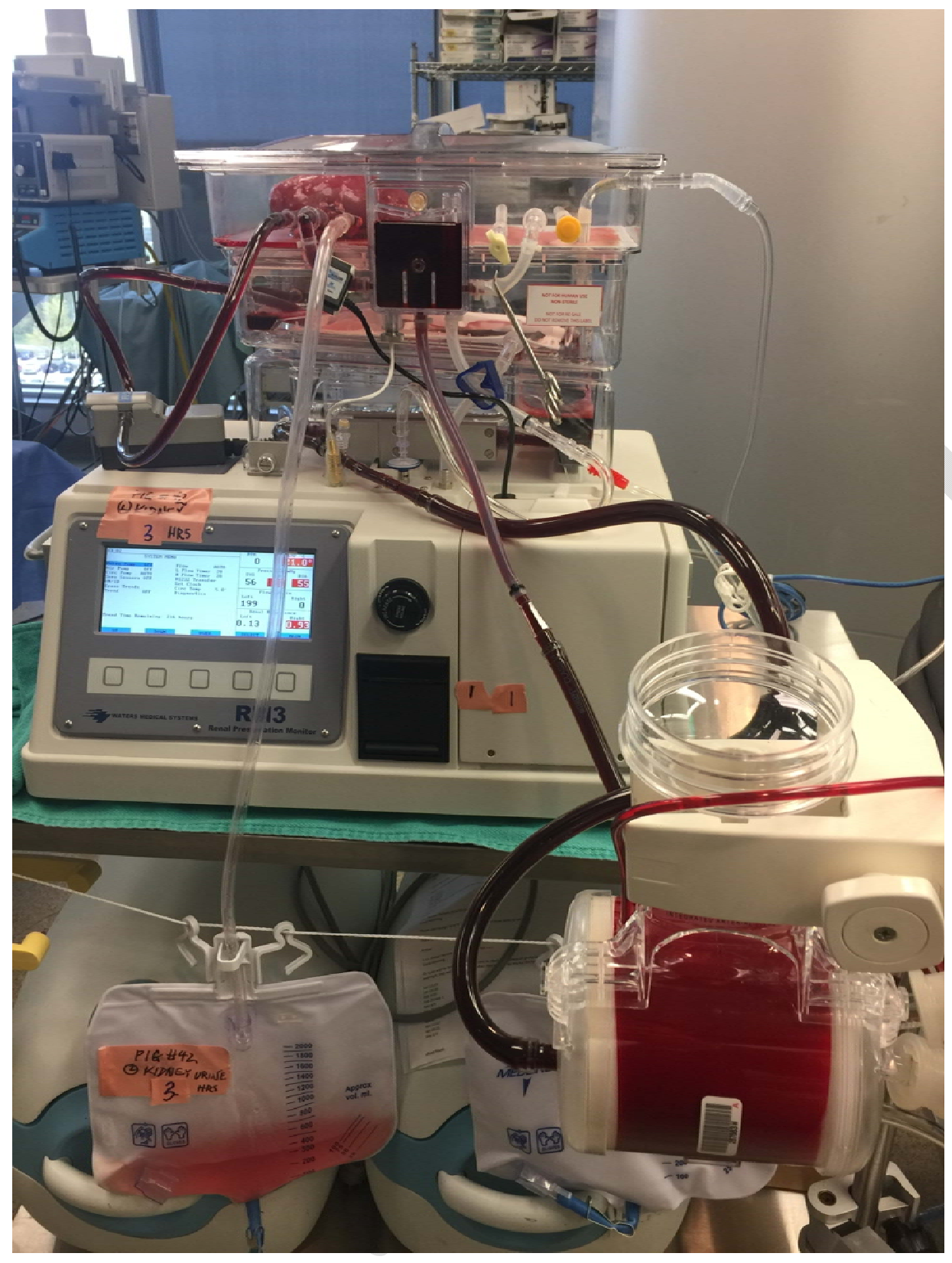


Fig. 6. Selected images from completely intracoporeal autotransplant performed by Dr. Jason Lee. (A) View of hilar dissection during the nephrectomy. (B) Completed vascular anastomosis prior to unclamping. Reprinted with permission. Lee JY, Alzahrani T, Ordon M. Intra-corporeal robotic renal auto-transplantation. Can Urol Assoc J 2015;9:E748-9.
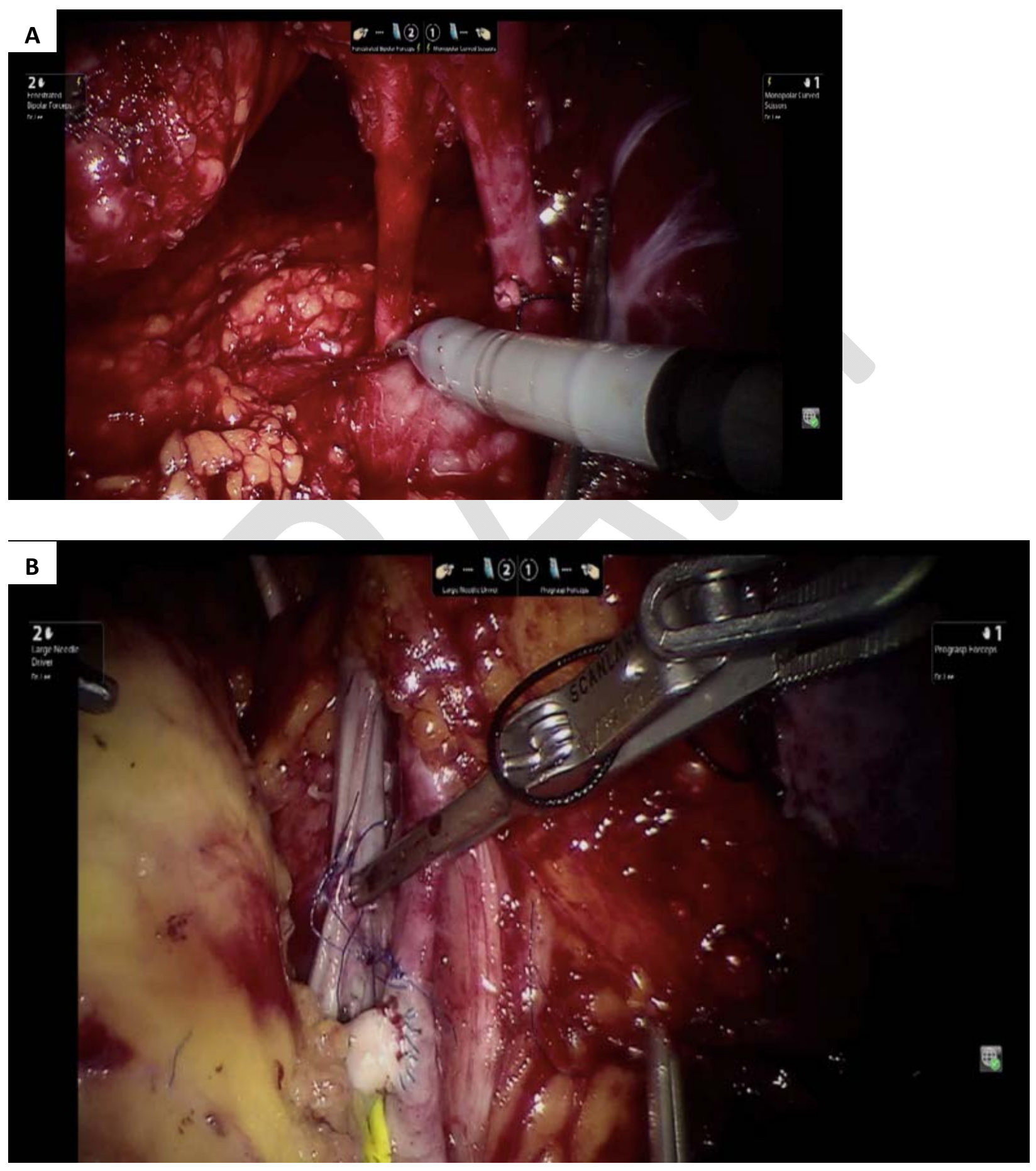


\begin{tabular}{|c|c|c|c|}
\hline \multicolumn{4}{|c|}{ First kidney transplant by center } \\
\hline Year & Transplant center & Type & Lead physicians \\
\hline 1952 & $\begin{array}{c}\text { Toronto General } \\
\text { Hospital, Toronto, } \\
\text { ON } \\
\end{array}$ & $\begin{array}{l}\text { First successful } \\
\text { deceased donor }\end{array}$ & Dr. Gordon Murray \\
\hline 1958 & $\begin{array}{c}\text { Royal Victoria } \\
\text { Hospital, Montreal, } \\
\text { QC }\end{array}$ & $\begin{array}{l}\text { Living donor } \\
\text { identical twins }\end{array}$ & $\begin{array}{l}\text { Drs. Ken McKinnon, } \\
\text { Joe Luke, and John } \\
\text { Dossetor }\end{array}$ \\
\hline 1963 & $\begin{array}{c}\text { Royal University } \\
\text { Hospital Saskatoon, } \\
\text { SK } \\
\end{array}$ & $\begin{array}{l}\text { Repeat kidney } \\
\text { transplant from } \\
\text { deceased donor } \\
\end{array}$ & $\begin{array}{c}\text { Drs. Marc Baltzan, } \\
\text { Casamir Wolan, } \\
\text { Manuel Ty }\end{array}$ \\
\hline 1967 & $\begin{array}{c}\text { University of Alberta } \\
\text { Hospital, Edmonton, } \\
\text { AB }\end{array}$ & Deceased donor & Dr. William Lakey \\
\hline 1967 & $\begin{array}{c}\text { Ottawa Civic } \\
\text { Hospital, Ottawa ON }\end{array}$ & $\begin{array}{c}\text { Living related } \\
\text { transplant }\end{array}$ & Drs. Irvine and Koch \\
\hline 1968 & $\begin{array}{c}\text { Kingston General } \\
\text { Hospital, Kingston, } \\
\text { ON }\end{array}$ & Deceased donor & Dr. Andrew Bruce \\
\hline 1968 & $\begin{array}{c}\text { Vancouver General } \\
\text { Hospital, Vancouver, } \\
\text { BC }\end{array}$ & Deceased donor & Not Available \\
\hline 1969 & $\begin{array}{c}\text { St. Michael's } \\
\text { Hospital, Toronto, } \\
\text { ON }\end{array}$ & Deceased donor & Dr. Nick Colapinto \\
\hline 1969 & $\begin{array}{c}\text { Hôpital Notre-Dame, } \\
\text { Montreal, QC }\end{array}$ & Deceased donor & Dr. Pierre Daloze \\
\hline 1969 & $\begin{array}{c}\text { Victoria General } \\
\text { Hospital, Halifax, NS }\end{array}$ & Deceased donor & $\begin{array}{c}\text { Drs. Allan } \\
\text { MacDonald and Stan } \\
\text { Lannon }\end{array}$ \\
\hline 1969 & $\begin{array}{c}\text { Hôpital } \\
\text { Maisonneuve, } \\
\text { Montreal, QC }\end{array}$ & Deceased donor & $\begin{array}{l}\text { Drs Paul Dessureault, } \\
\text { Michel Auger, Paul- } \\
\text { Eugène Bertrand, } \\
\text { Rolland Lévy, } \\
\text { Jacques Brière }\end{array}$ \\
\hline
\end{tabular}




\begin{tabular}{|l|c|c|c|}
\hline 1969 & $\begin{array}{c}\text { Health Sciences } \\
\text { Center, Winnipeg, } \\
\text { MB }\end{array}$ & Deceased donor & Dr. Allan Downs \\
\hline 1972 & $\begin{array}{c}\text { University Hospital, } \\
\text { London, ON }\end{array}$ & Deceased donor & $\begin{array}{c}\text { Drs. Cal Stiller, John } \\
\text { Sharpe, Lloyd } \\
\text { McAninch }\end{array}$ \\
\hline 1972 & $\begin{array}{c}\text { L'Hôtel-Dieu de } \\
\text { Québec, Quebec City, } \\
\text { QC }\end{array}$ & $\begin{array}{c}\text { Living related } \\
\text { transplant }\end{array}$ & $\begin{array}{c}\text { Drs. Roméo Charrois } \\
\text { and Gilles Laroche }\end{array}$ \\
\hline 1974 & $\begin{array}{c}\text { McMaster University, } \\
\text { Hamilton, ON }\end{array}$ & Living donor & $\begin{array}{c}\text { Drs. Peter Knight, } \\
\text { Art Shimazu }\end{array}$ \\
\hline
\end{tabular}

The individuals and hospitals involved with the first transplants throughout Canada are incompletely represented in this table. However, the table provides a general outline of the date, individuals and procedures performed during the early era of transplantation. 